\title{
ECOLOGY OF THE LONG-TAILED SKUA, STERCORARIUS LONGICAUDUS, AT SCORESBY SUND, EAST GREENLAND
}

\author{
PART FOUR: BREEDING SUCCESS AND GROWTH OF YOUNG
}

by

\section{J. DE KORTE}

\author{
Institute of Taxonomic Zoology (Zoölogisch Museum), University of Amsterdam, \\ P.O. Box 20125, 1000 HC Amsterdam, The Netherlands
}

\section{ABSTRACT}

Breeding success and growth of young of Long-tailed Skuas were investigated in Northeast Greenland at Kap Stewart in 1973 and 1974, at Ugleelv and Kærelv in 1975, and at Karelv in 1979. Territorial pair density was positively correlated with the percentage snow-free area in June. In 1973, estimated mean egg production per territorial pair was 1.4, but no young hatched. Egg loss was due to predation by Arctic Foxes, Alopex lagopus. In 1974 no eggs were produced due to scarcity of food on the tundra. In 1975 and 1979, estimated mean egg production per territorial pair was 1.2 and 1.9 , respectively, and young did hatch, but none of them fledged. In both these years two-thirds of overall egg and chick mortality was caused by Arctic Foxes. Survival time of clutches and young in the different breeding years was negatively correlated with the number of foxes per unit of snow-free area. High breeding success of Long-tailed Skuas in Northeast Greenland occurs only in years with moderate to high food availability, a relatively low number of foxes and early to rather early disappearance of snow cover. Chicks gained weight rapidly from the first day to 12 or 13 days after hatching, when fast growth of culmen and tarsus stopped, and growth of wing slowed down. During the first two weeks in 1975 first-hatched chicks were heavier than second-hatched chicks of the same age and single chicks were similar to first-hatched chicks. The two longest surviving chicks reached an age of 24 and 25 days, at which time they had not yet fledged. Chicks and parents showed a circadian rhythm with greatest activity during the day and a period of sleep during the night in which the sun does not set at this latitude. The female stayed closer to the young than the male, but the male provided food more frequently.

\section{RÉSUMÉ}

Des recherches sur le succès de la reproduction et sur le développement de la progéniture des Labbes longicaudes ont été effectuées au Groënland du nord-est, au Cap Stewart en 1973 et 1974, à Ugleelv et Kærelv en 1975, et à Kærelv en 1979. La densité territoriale des paires est en corrélation positive avec le pourcentage atteint en juin par les zones déneigées. En 1973, la production moyenne d'oeufs par paire territoriale a été estimée à 1,4 , mais il n'y a pas eu d'éclosion, la perte des oeufs étant due à la prédation par les Renards arctiques, Alopex lagopus. En 1975 et 1979 la production moyenne d'oeufs par paire territoriale a été estimée à 1,2 et respectivement à 1,9 , et il y a eu d'éclosion, mais aucun des poussins n'a acquis la capacité de voler. Pendant ces deux années, la mortalité des oeufs et des poussins a été provoquée pour les deux tiers par les Renards arctiques. Le temps de survie des pontes et des poussins dans les diverses années est en corrélation négative avec le nombre des renards par unité de terrain déneigé. En Groënland du nord-est la reproduction est vraiment couronnée de succès seulement pendant les années caractérisées par des ressources alimentaires assez abondantes ou abondantes, par un nombre relativement bas de renards, et par le déneigement précoce ou assez précoce. Les poussins gagnent rapidement du poids à partir du 1er jour jusqu'à 12-13 jours après l'éclosion, quand on enregistre l'arrêt de la croissance rapide du culmen et du tarse ainsi qu'un ralentissement de la croissance des ailes. Pendant les deux premières semaines, en 1975, les premiers poussins éclos ont été plus lourds que eux éclos ultérieurement, les poussins isolés étant similaires à ceux de la 1ère catégorie. La longévité maximum a été atteinte par deux poussins atteignant 24 et 25 jours; à cet âge ils ne pouvaient pas encore voler. Poussins et parents montrent un rythme circadien, avec activité maximale diurne et une période de sommeil pendant la nuit (il n'y a pas de coucher du soleil à cette latitude). La femelle se maintient plus au voisinage de la progéniture que le mâle, mais le mâle procure plus fréquemment la nourriture.

\section{CONTENTS}

1. Abstract/Résumé ............................... 1

2. Introduction................................... 2

3. Material and methods ............................ 2

3.1. General .................................... 2

3.2. Clutch survival........................... 2

3.3. Growth equations ........................ 3

3.4. Food availability and predation indices.... 4 
4. Results

4.1. Hatching success

4.2. Fledging success

4.3. Growth of young

4.4. Chick and parental behaviour

4.5. Potential predators

5. Discussion

5.1. Growth of body mass and appendages.....

5.2. Mortality factors

5.3. Adult mortality and recruitment..............

5.4. Densities

5.5. Conclusions

6. Acknowledgements

7. References
5.6. Robustness of conclusions and perspective

\section{INTRODUCTION}

In 1973, 1974 and 1975 the breeding biology of the Long-tailed Skua was studied at Scoresby Sund, Northeast Greenland. Earlier papers in this series dealt with distribution and densities (De Korte, 1977), arrival, site tenacity and departure (De Korte, 1984), and clutch size and laying date in relation to body energy reserves (De Korte, 1985). In 1979, Hansen (undated, 1981 in lit., 1982, 1984) carried out a study in the 1975 study area at Kærelv and his results are incorporated in this paper.

The first Long-tailed Skuas arrived on the tundra, singly or in small groups, in the last week of May. They established territories in areas with snow-free patches within a few days after arrival. Territorial birds frequented their territories until August and many returned in the following years. They arrived with maximal energy reserves and strongly enlarged gonads. Loss of energy reserves in the pre-breeding period determined clutch size. Females did not lay at all when they lost more than $25 \%$ of their arrival energy reserves during the pre-breeding period. Timing of egg laying was correlated with the age of the pair and with snow cover. One-egg and two-egg clutches found (re-lays not included) had the same average date of completion (13 June, range 4 June - 5 July). Gonads started to regress at or soon after incubation of eggs. All territorial birds developed brood patches whether they were incubating eggs or not.
In this paper, hatching and fledging success, growth of young, parental care, mortality factors and recruitment are treated. The next paper in this series will deal with food and feeding habits.

\section{MATERIAL AND METHODS}

\subsection{General}

From the last week of May (in 1973 from the second week of June) until the third week of June we visited (on skis and on foot) each section of our study areas (De Korte, 1977) about every third day. The behaviour of territorial pairs was observed to obtain a clue for the location of nests. After nests with eggs had been found, they were checked every two days. About three days before hatching, cracks appear on the surface of the egg (De Korte, 1985). One to two days before hatching the egg is pipped. After the first observation of cracks, checks were made daily in order to ascertain hatching date. On the day of hatching (conventionally called day 0, Ricklefs, 1983) chicks were banded with plastic tapes of different colour combinations, and when sufficiently large they were ringed with aluminium rings from the Zoological Museum in Copenhagen (ZMK) and with plastic colour rings of a unique combination.

Some days before hatching, two nests (a oneegg clutch and a two-egg clutch) were enclosed with $2 \mathrm{~cm}$ poultry mesh, $30 \mathrm{~cm}$ in height and 3 $m$ in diameter. This technique has been used by other workers with good results (Maher, 1970, 1974; LeCroy \& Collins, 1972; LeCroy \& LeCroy, 1974). It was readily accepted by the breeding birds. Since chicks are free running soon after hatching and hide among the vegetation, this enclosure enabled us to find the chicks quickly and to observe closely both chicks and parents from a hide placed about $25 \mathrm{~m}$ away.

\subsection{Clutch survival}

Survival time of clutches is calculated as time between clutch initiation date and the in- 
termediate date between last observation of the clutch and date at which the nest was found empty (for methods of estimating egg age, see Furness \& Furness, 1981; De Korte, 1985).

For survival time of young, I similarly computed the mean of the age at last observation and the age at the day it was found dead or at which it was found to be missing and the parents' behaviour indicated it was no longer alive.

In 1973 nesting had already begun when we arrived in the study area at Kap Stewart (13 June). At that time some clutches might have failed already and could have been overlooked. Assuming that survival rate of clutches was about the same during the incubation period I used the method proposed by Mayfield (1961, 1975) for estimation of total number of clutches laid in respective study areas and years. Daily mortality $r=b / a$, in which $b=$ number of clutches proved to be lost and $a=$ number of nestdays exposure during observation. This gives a daily survival rate $s=1-r=\frac{a-b}{a}$. Probability of survival of clutches for a period of $d$ days $=$ $s^{d}$. Estimated mean survival times of eggs were calculated by taking into account the early clutches that were probably missed.

\subsection{Growth equations}

Chicks were weighed and measured daily from day 0 . It took about 12 hours to visit all chicks in the study area and nests were visited each day in the same sequence. Thus a given chick was handled at about the same time of the day on each day. After three weeks, weight fluctuated as much as $44 \mathrm{~g}$ within 24 hours (fig. 4). Because different chicks were weighed at different times of the day, weighing time may be a factor to be taken into account when comparing different chicks. In the first days after hatching, weights were taken with a $30 \mathrm{~g}$ spring balance to the nearest $0.1 \mathrm{~g}$ and with a $100 \mathrm{~g}$ spring balance to the nearest $0.5 \mathrm{~g}$; later, weights were taken with a $300 \mathrm{~g}$ spring balance to the nearest $1.0 \mathrm{~g}$. Wing length (manus including primary feathers) was taken with a ruler to the nearest $\mathrm{mm}$ by measuring the maximum chord from the carpal joint to the tip of the longest primary. Tarsus length and culmen length (from tip to base of feathering) were taken with a pair of calipers to the nearest 0.1 $\mathrm{mm}$.

Seven chicks (three singles, two pairs of siblings) were weighed at the day of hatching. Due to early mortality and to the failure of finding the free running chicks every day, the series of weights and measurements until 24 days after hatching is complete only for one single free chick and one single enclosed chick.

As it became apparent that growth of wing, tarsus and culmen was not logarithmic, and increase of weight was logarithmic for a short period only (fig. 3), measurements and weights are presented on a linear grid in fig. 4. For comparison of growth of our chicks with chicks studied by Maher $(1970,1974)$, relative instantaneous growth rate in intervals between weighings, was calculated with the formula $K_{(b)}=\frac{\log W_{2}-\log W_{1}}{T_{2}-T_{1}}$ (Brody, 1945). This formula has only been applied to the first two weeks of life when the increment between weighings is logarithmic even though over the entire nestling period it is not.

As single young and senior siblings generally follow the same growth pattern in Stercorariidae (Reid, 1966; Osborne, 1985) and junior siblings have a relatively retarded growth (figs. 3 \& 4) single young and senior siblings are pooled and treated separately from junior siblings in table IV. Because of the apparent weight drop in junior siblings during the first day their instantaneous relative growth rate $K_{(b)}$ is calculated for them from day 1 and not from day 0 , as was done for single chicks and senior siblings. Mean daily gains and instantaneous relative growth rates are calculated by comparing weights of the same chicks on different days and not by comparing overall means.

In order to facilitate a comparison with growth rates in other species I employed the graphical method of Ricklefs (1967) to fit 
logistic or Gompertz equations to the growth curves of body weight and wing length. Time required to grow from 10 to $90 \%$ of asymptotic values is also given because it permits a comparison of growth rates fitted to different growth curves. Growth of body weight was most adequately described by the logistic equation where body mass at age $t$ is given by:

$W_{t}=\frac{A}{1+e^{-k\left(t-t_{i}\right)}}$, in which $A=$ asymptotic weight, $k=$ growth constant, and $t_{i}=$ age in days at which the inflection point of the growth curve $(0.500 A)$ is reached (9.1 days at Kærelv in 1975). The ratio asymptotic weight/adult weight in Stercorariidae is given as 0.96 (Reid, 1966; Ricklefs, 1968) which gives an asymptotic weight of $277 \mathrm{~g}$ in the Long-tailed Skua (see table V). For calculating $k$ for the logistic weight curve of the mean weight of two chicks I only used their weights until day 15 , when one of them stopped gaining weight.

Growth of wing was most adequately described by the Gompertz equation in which wing length at age $t$ is given by:

$L_{t}=A e^{-k-k\left(t-t_{i}\right)}$ where $k=$ growth constant and $t_{i}=$ age in days at which the inflection point of the growth curve $(0.368 A)$ is reached $(11.7$ days at Kærelv in 1975). For asymptotic wing length, I used the wing length of juveniles of the year wrecked in the Netherlands in the months of August and September (15 specimens in the Zoölogisch Museum in Amsterdam (ZMA)). Their mean wing length 299.8 (S.D. = 6.4) is on average $9 \mathrm{~mm}$ shorter than in adults (table V). For calculating $k$ in the Gompertz equation for wing length curve I used the mean wing lengths of two chicks from day 3 (when wings started to grow) until day 24 , when one of the chicks disappeared.

Since tarsus length and culmen length are quite variable in adults (De Korte, 1985) as well as in chicks and as these lengths are difficult to measure exactly in small chicks, I refrained from fitting growth curves of more sophisticated equations than linear ones to them.

Wing length in Long-tailed Skuas is less variable than weight and length of tarsus and culmen (De Korte, 1985). Moreover, the wing is easier to measure and it continues to grow quite fast and at a constant rate in the period when weight and tarsus and culmen length show little gain (third and fourth week after hatching, see fig. 4). Factors adversely affecting weight may also affect wing growth, but with something like a 3- to 5 day lag so that the overall effect is smoothed (LeCroy \& LeCroy, 1974; Furness, 1983). Therefore I considered wing length as the most reliable age indicator for growing young for which hatching dates were unknown, using it to estimate age of such chicks for which status (single, senior sibling or junior sibling) was known. Their weights, culmen lengths and tarsus lengths have been plotted according to age estimation in fig. 4 .

\subsection{Food availability and predation indices}

In some years several pairs did not lay eggs and therefore the average egg production per pair in a population may be lower than the mean clutch size (table I). The former measure is of greater interest since it provides an estimate of natality rate per pair. Mean clutch biomass per territorial pair is probably a better relative measure for food availability in respective years than mean clutch biomass per breeding pair. As we had probably missed several clutches (see above), in practice the last measure is better. However, clutch biomass may not only be influenced by food availability but also by body size (Väisänen et al., 1972), age and experience of the parents (Davis, 1975; Furness, 1983), by laying date (Furness, 1983; O'Donald, 1983; Osborne, 1985) and by heredity (Ojanen et al., 1979; Van Noordwijk et al., 1980; Furness, 1983), and therefore we require a measure which is independent of these factors.

In Northeast Greenland the Collared Lemming, Dicrostonyx groenlandicus, is a very important item of the diet of both the Long-tailed Skua and the Arctic Fox, especially in years of successful reproduction (Manniche, 1910; Pedersen, 1926, 1930; Salomonsen, 1950; De Korte, in prep.). Summer food availability on the tundra has a positive correlation with reproductive success in foxes (Pedersen, 1926, 
1930; Elton, 1965; Vibe, 1967; Macpherson, 1969).

In the Scoresby Sund area, the Greenlandic hunters catch and shoot foxes during the winter when the foxes are in their winter pelage. The number of fox furs per year in the hunting statistics supplied by the Ministry of Greenland refer to the furs purchased by the Royal Greenland Trade Department between two successive summers (Vibe, 1967, 1985 in lit.). Thus furs purchased between summer 1972 and summer 1973 are given as the catch for 1973. Assuming that the catching effort of the trappers during the years of our study has been about the same (Born, 1983; Sandell \& Sandell, 1984) the numbers of furs purchased in different years can be used as a food availability index in the respective preceding years. The fact that the numbers of furs purchased showed a significant positive correlation $\left(r^{2}=0.96\right.$, $n=4$ ) with the observed mean clutch biomass per breeding pair in the preceding year supports the assumption that this is a trustworthy index. Arctic Foxes are the most important egg and chick predators in Scoresby Sund (De Korte et al., 1981, this study) and therefore numbers of fox furs can be used as a predation index in the respective years in which the furs had been purchased. Since foxes seek food mainly in snow-free areas on the tundra, an extensive snow cover will make the foxes concentrate in snow-free spots. Therefore the percentage of tundra covered by snow in June, which is the egg-laying time of the Long-tailed Skuas (De Korte, 1985), can be used in combination with the fur statistics to obtain an index of predation effort per fox per unit of snow-free area.

\section{RESULTS}

\subsection{Hatching success}

Tables I and II present egg production and the fate of 35 clutches found in different years and areas. The data for Kærelv 1979 have been derived from Hansen (1981 in lit., 1982, 1984). Estimated numbers of clutches and eggs and estimated mean survival time of eggs, including the ones we probably had missed, are given in parentheses.

In 1973 at Kap Stewart, clutch daily survival rate was 0.90 and probability of clutch survival for the entire incubation period (24 days) was $8 \%$. No eggs survived until hatching in the study area. Similarly in other areas like Flakkerhuk, Modiolaelv, Kærelv, Gurreholm, Kjoveland (De Korte, 1977), no young were seen in July and August.

In 1974 no eggs were found in the study area at Kap Stewart nor in the adjacent area of Modiolaelv and the valley of Gåseelv. Status of gonads and body energy reserves of collected specimens (De Korte, 1985) also indicated that no eggs were produced in the Scoresby Sund area.

In 1975 at Kærelv, clutch daily survival rate was 0.98 and probability of clutch survival for the incubation period was $62 \%$, whereas $65 \%$ of the total number of eggs found survived. Seven (four 1-egg, three 2-egg) of the 14 clutches found in the Kærelv study area (eight 1egg, six 2-egg) hatched successfully. One 1-egg clutch was deserted by the parents after nine days of poor attendance during which the egg lost little weight compared with standard weight loss of a well-incubated egg (De Korte, 1985). After another three days I collected the egg. It appeared fresh and no embryo could be discovered. In one 2-egg clutch the embryos died in the period between cracking and pipping as a result of poor attendance and consequent cooling of the eggs (De Korte, 1985). Five clutches (three 1-egg, two 2-egg) were predated. If we include in survival time all clutches which survived until 24 days (hatched ones and those with dead embryos), the mean survival time was 22.1 days (table II, fig. $5 \mathrm{~A}, \mathrm{~B}$, C). The valley of Ugleelv was visited only three times during the breeding period in 1975 and for an estimation of total number of clutches laid I assumed that clutch survival rate $(0.98)$ and hatching success $(50 \%)$ was the same as at Kærelv which resulted in an estimation of a total of five eggs to have hatched there.

In 1979 at Kærelv, clutch daily survival rate was 0.97 ; probability of clutch survival for the 
TABLE I

Egg production found at Scoresby Sund in different years and areas. In parentheses calculated probable values.

\begin{tabular}{|c|c|c|c|c|c|c|c|c|c|c|c|c|}
\hline \multirow[t]{2}{*}{ Year } & \multirow[t]{2}{*}{ Study area } & \multirow{2}{*}{$\begin{array}{l}\mathrm{Km}^{2} \\
n\end{array}$} & \multirow{2}{*}{$\begin{array}{l}\text { Terr. } \\
\text { pairs } \\
n\end{array}$} & \multirow{2}{*}{$\begin{array}{l}\text { Breed. } \\
\text { pairs } \\
n\end{array}$} & \multirow{2}{*}{$\begin{array}{l}\text { Eggs } \\
n\end{array}$} & \multicolumn{2}{|c|}{ Clutch size } & \multicolumn{2}{|c|}{ Clutch biomass (g) } & \multirow{2}{*}{$\begin{array}{l}\text { Terr. p. } \\
\text { per } \mathbf{k m}^{2}\end{array}$} & \multirow{2}{*}{$\begin{array}{l}\text { Breed. p. } \\
\text { per } \mathbf{k m}^{2}\end{array}$} & \multirow{2}{*}{$\begin{array}{l}\text { Clutch } \\
\text { biom. (g) } \\
\text { per } \mathbf{k m}^{2}\end{array}$} \\
\hline & & & & & & $\begin{array}{l}\text { per } \\
\text { terr.p. }\end{array}$ & $\begin{array}{l}\text { per } \\
\text { breed.p. }\end{array}$ & $\begin{array}{l}\text { per } \\
\text { terr.p. }\end{array}$ & $\begin{array}{l}\text { per } \\
\text { breed.p. }\end{array}$ & & & \\
\hline 1973 & Kap Stewart & 30 & 12 & $6(11)$ & $9(17)$ & $0.8(1.4)$ & 1.5 & $31(57)$ & 59 & 0.4 & $0.2(0.4)$ & $12(22)$ \\
\hline 1974 & Kap Stewart & 30 & 6 & 0 & 0 & 0 & 0 & 0 & 0 & 0.2 & 0 & 0 \\
\hline 1974 & Modiolaelv & 16 & 9 & 0 & 0 & 0 & 0 & 0 & 0 & 0.6 & 0 & 0 \\
\hline 1975 & Ugleelv & 9 & 8 & $5(7)$ & $7(10)$ & $0.9(1.3)$ & 1.4 & $39(55)$ & 52 & 0.9 & $0.6(0.8)$ & $35(49)$ \\
\hline 1975 & Karelv & 26 & 16 & $14(14)$ & $20(20)$ & $1.2(1.2)$ & 1.4 & $49(49)$ & 56 & 0.6 & $0.5(0.5)$ & $30(30)$ \\
\hline 1979 & Karelv & 26 & 10 & $8(9)$ & $17(19)$ & $1.7(1.9)$ & $2.1(2.3)$ & $74(92)$ & $93(102)$ & 0.4 & $0.3(0.3)$ & $29(36)$ \\
\hline
\end{tabular}

TABLE II

Breeding success found at Scoresby Sund in different years and areas. Data for 1979 after Hansen (1981 in lit., 1982, 1984) include two 1-egg re-lays and exclude a first 2-egg clutch. In parentheses calculated probable values.

\begin{tabular}{|c|c|c|c|c|c|c|c|c|c|c|c|c|c|c|}
\hline \multirow[t]{2}{*}{ Year } & \multirow[t]{2}{*}{ Study area } & \multicolumn{2}{|c|}{$\begin{array}{l}\text { Eggs } \\
\text { hatched }\end{array}$} & \multicolumn{2}{|c|}{$\begin{array}{l}\text { Eggs } \\
\text { predated }\end{array}$} & \multicolumn{2}{|c|}{$\begin{array}{l}\text { Egss addled } \\
\text { embr. dead }\end{array}$} & \multicolumn{2}{|c|}{$\begin{array}{l}\text { Eggs } \\
\text { deserted }\end{array}$} & \multicolumn{2}{|c|}{$\begin{array}{l}\text { Egg surv. time } \\
\text { (days) }\end{array}$} & \multicolumn{2}{|c|}{$\begin{array}{l}\text { Young surv. } \\
\text { time (days) }\end{array}$} & \multirow{2}{*}{$\begin{array}{l}\text { Young } \\
\text { fledged } \\
n\end{array}$} \\
\hline & & $n$ & $\%$ & $n$ & $\%$ & $\bar{n}$ & $\%$ & $n$ & $\overline{\%}$ & range & mean & range & mean & \\
\hline 1973 & Kap Stewart & 0 & & $9(15)$ & 100 & 0 & & 0 & & $6-21$ & $10.7(6.9)$ & 0 & & 0 \\
\hline 1974 & Kap Stewart & 0 & & 0 & & 0 & & 0 & & 0 & & 0 & & 0 \\
\hline 1974 & Modiolaelv & 0 & & 0 & & 0 & & 0 & & 0 & & 0 & & 0 \\
\hline 1975 & Ugleelv & (5) & (50) & $?$ & & $?$ & & $?$ & & $?$ & $?$ & $?$ & & 0 \\
\hline 1975 & Karelv & 10 & $50(50)$ & $7(7)$ & $35(35)$ & 2 & $10(10)$ & 1 & $5(5)$ & $14-24$ & $22.1(21.0)$ & $1-25$ & 13 & 0 \\
\hline 1979 & Karelv & 4 & $27(24)$ & $6(8)$ & $40(47)$ & 4 & $27(24)$ & 1 & $7(6)$ & $9-24$ & $19.0(17.6)$ & $2-?$ & $?$ & 0 \\
\hline
\end{tabular}

incubation period was $52 \%$, whereas $58 \%$ of the eggs found survived. Ten clutches (seven 2 egg, three 1-egg) were found at Kærelv. Of these, one 2-egg clutch and one egg out of two other 2-egg clutches hatched successfully. One pair produced two successive 1-egg replacements after their original 2-egg clutch had been destroyed accidentally by the observers (original clutch omitted from values of table II). Four clutches (two 2-egg, two 1-egg replacements) were lost to predators. In three 2egg clutches one of the eggs proved to be addled. In one egg in a 2-egg clutch the embryo died just prior to hatching. One 1-egg replacement was poorly attended by the parents and did not hatch. Mean survival time of clutches found was 19.0 days (table II, fig. 5 A, B, C), including all eggs surviving to hatching and those that failed to hatch but survived until 24 days.

\subsection{Fledging success}

In 1975 at Kærelv, ten young (four singles, three pairs of siblings) hatched between 30 June and $13 \mathrm{July}$, but none of them fledged as they all died 1 to 25 days after hatching (table III). One pair of siblings died one and two days after the chicks had hatched during a day of inclement weather. Two other pairs of siblings, and two single chicks disappeared when the chicks were about two weeks old. Two other single chicks lived for 24 and 25 days respectively. If we exclude the two found dead within three days after hatching, the mean survival time of all chicks was 15.9 days, range 9-25.5 days (cf. table II).

In 1975 in the valley of Ugleelv, five young were supposed to have hatched, but only one was seen at day one, and found dead the following day (10 July). It appears that no young had fledged there either. Roaming juveniles of the year were not seen at all in August, a month in which they are usually seen away from their area of birth (Maher, 1970, 1974; Taylor, 1974; Meltofte et al., 1981).

In 1979 at Kærelv, four young from 2-egg clutches were not seen after a few days after hatching and probably none of them survived to fledging. In the valley of Gåseelv a fledged 
TABLE III

Age at death of 10 young hatched 30 June-13 July 1975 at Kærelv.

\begin{tabular}{|c|c|c|c|c|c|c|}
\hline & \multirow{2}{*}{$\begin{array}{l}1 \text { st } \\
\text { week }\end{array}$} & \multirow{2}{*}{$\begin{array}{l}2 \text { nd } \\
\text { week }\end{array}$} & \multirow{2}{*}{$\begin{array}{l}3 \text { rd } \\
\text { week }\end{array}$} & \multirow{2}{*}{$\begin{array}{l}\text { 4th } \\
\text { week }\end{array}$} & \multicolumn{2}{|c|}{ Survival time (days) } \\
\hline & & & & & mean & range \\
\hline Singles (4) & & 1 & 1 & 2 & 18.2 & $9-25$ \\
\hline Senior siblings (3) & 1 & 1 & 1 & & 10.3 & $2-15$ \\
\hline Junior siblings (3) & 1 & 2 & & & 8.7 & $1-14$ \\
\hline All chicks (10) & 2 & 4 & 2 & 2 & 13.0 & $1-25$ \\
\hline
\end{tabular}

juvenile was seen on 2 August (Hansen, 1982, 1984).

\subsection{Growth of young}

At hatching, chicks had a white horny egg tooth which persisted distinctly until day 5 and then disappeared progressively (fig. 1). The bill was a shiny grey-blue at hatching, followed by a gradual intensification of colour. It was still blue in the fourth week, though the tip had turned black. Juveniles of the year wrecked in autumn in the Netherlands also had a blue bill.

Tarsus and front toes were blue grey at hatching, and webs and hindtoe were unpigmented, being a watery pink in colour. At the end of the second week the distal parts of toes and webs started to turn black rapidly and in the fourth week about $50 \%$ of the foot surface had turned black (for method of measuring black, see De Korte, 1985). A just fledged specimen in ZMK (46.2331) had $71 \%$ of the foot black. In the course of life, the speed of blackening slows down and the tarsus never becomes completely black (De Korte, 1985).

The primaries started to emerge on day 4 or day 5 (fig. 1) with the ninth primary being longer than the tenth in the pre-fledging stage and in the first weeks after fledging (fig. 2). A fledged specimen from 17 August, about 5 weeks old (ZMK 46.293), and one from 26 August, about 7 weeks old (ZMK 46.971), both from the breeding grounds in Northeast Greenland, and one from 5 September wrecked in the Netherlands (ZMA 27.859) have $P_{10}$ still growing and shorter than $P_{9}$. Fourteen other juvenile specimens in ZMA from late August and September have $P_{10}$ longer than $P_{9}$.
Two chicks found dead on their second day and one on its third day still had yolk in their lower abdomen.

The weight within 24 hours after hatching of seven chicks varied from 25.0 to $29.5 \mathrm{~g}$ (mean 26.5 ). Their weight varied from $66 \%$ to $71 \%$ (mean 68\%) of the fresh weight of the eggs from which they hatched. Four chicks weighed by Hansen (1982) at Kærelv in 1979, when eggs were on average $5 \mathrm{~g}$ heavier than in 1975 (De Korte, 1985) ranged from 27.0 to $35.0 \mathrm{~g}$ (mean 29.9). Table IV presents weights, mean daily weight gains and mean instantaneous relative growth rate $K_{(b)}$ from the start of growth until the end of rapid body growth (day 13, see fig. 4).

During the first day of life the weight of nestlings may remain quite stable or may decrease (figs. 3 \& 4; Maher, 1970; Andersson, 1976a).

The chicks rapidly gained weight from day 1 until day 12 or 13 . A short phase of maximal growth rate is evident from day 1 to day 5 (fig. $3)$. Thereafter growth rate gradually declined. Mean absolute growth rate (g fresh weight per day) in the linear period of growth (day 6-12), characteristic of birds midway in their development and almost identical to the most rapid absolute growth (Hussell, 1972) was $16.3 \mathrm{~g}$ per day.

The weight curves for the enclosed single chick and the free chick show some differences. The enclosed chick gained more weight than the free chick. Until day $10, \mathrm{~K}_{(b)}$ of the free chick was 15.6 and of the enclosed chick 18.3, which was similar to that of a senior sibling (18.2) in the same period. Its junior sibling had a $K_{(b)}$ of 17.2 (from day 1 to day 11 ). In the period of maximal daily weight gain the free 


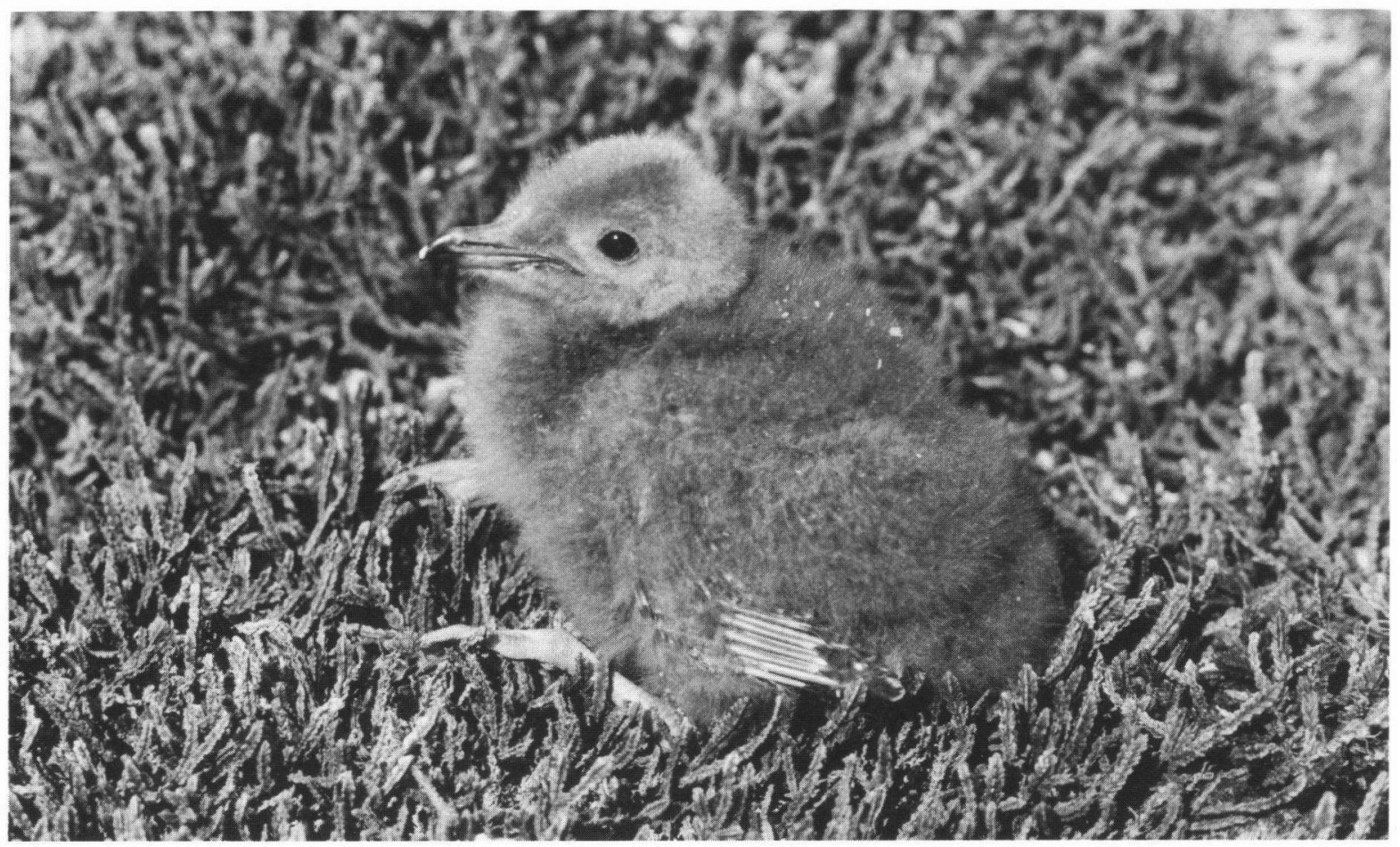

Fig. 1. Young of the Long-tailed Skua, 9 days after hatching, Kærelv 1975. Photograph J. de Korte.

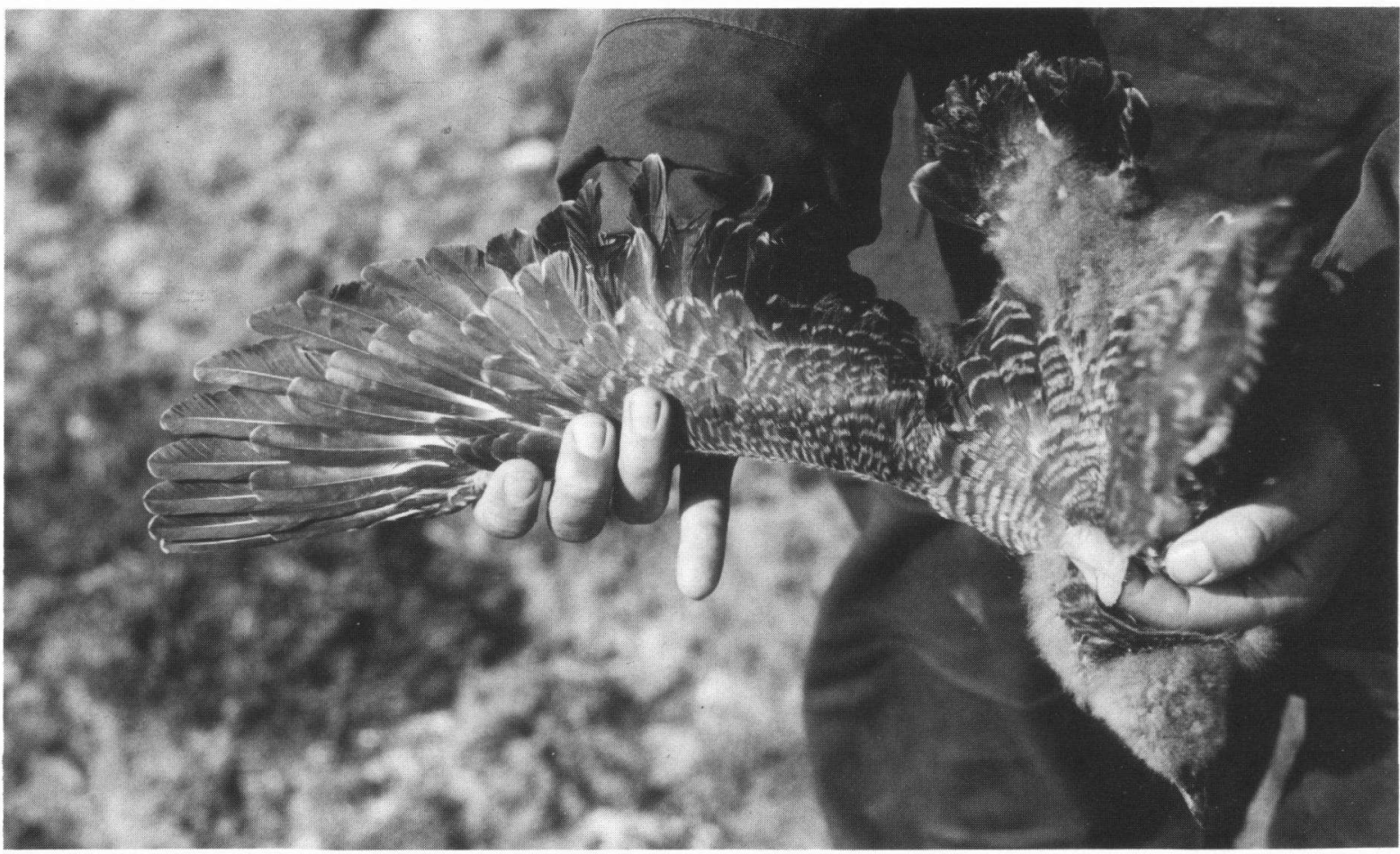

Fig. 2. Young of the Long-tailed Skua, 23 days after hatching, Kxrelv 1975. Photograph J. de Korte. 


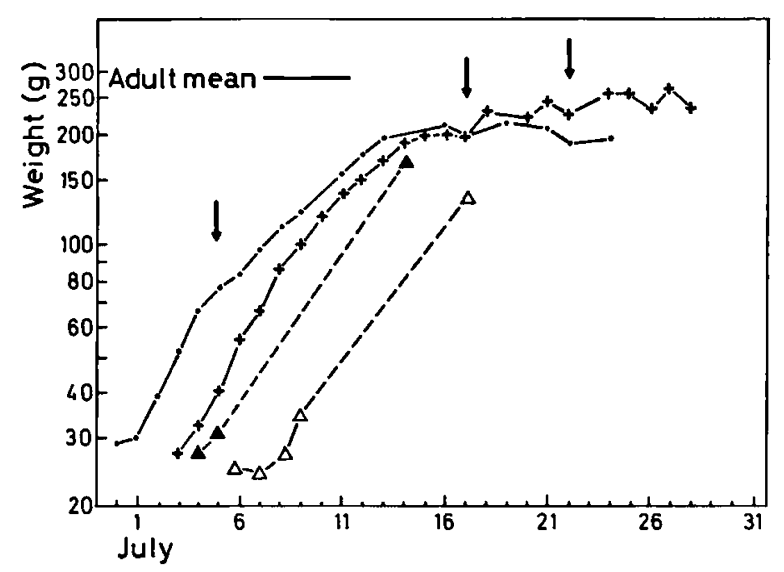

Fig. 3. Semi-logarithmic weight curves of four chicks at Kærelv 1975 in relation to date. Arrows indicate days with inclement weather. Other symbols are explained in fig. 4.

chick gained $15.8 \mathrm{~g}$ per day and the enclosed chick gained $16.8 \mathrm{~g}$ per day. After day 19 the enclosed chick still gained weight, whereas the free one showed a tendency to lose weight.

A logistic curve fit (Ricklefs, 1967) to the means of daily weight of the free and enclosed chicks combined from day 0 until day 16 resulted in the equation $W_{t}=\frac{277}{1+e^{-0.232(t-9.1)}}$. According to this equation, the time required to grow from $10 \%$ to $90 \%$ of asymptotic weight ( $t_{10}-t_{90}$ in Ricklef's notation) was 18.5 days.

A Gompertz curve fit to the means of daily wing length of the free and the enclosed chick (fig. 4) from day 3 until day 24 resulted in the equation $L_{t}=300 e^{-0.082^{-0.082(t-11.7)}}$. According to this equation the time required for the wing to grow from $10 \%$ to $90 \%$ of asymptotic length is 39 days. Mean absolute growth rate (mm per day) during the second week was 10.9 , during the fourth week it was 5.5. Age of chicks found after hatching and whose status (single, senior sibling, junior sibling) was known, was estimated with help of wing length. Their weights, culmen lengths and tarsus lengths have been plotted according to age estimation in fig. 4 and their weights are also taken into account in table IV. A fledged juvenile specimen still

TABLE IV

Weights and weight gain $(\mathrm{g})$ of chicks at different age. $\mathrm{S}=$ single chick and senior sibling chick; $\mathrm{J}=$ junior sibling chick; a includes chick with age estimated from wing length; $K_{(b)}=$ relative instantaneous growth rate after Brody (1945).

\begin{tabular}{ccccccccc}
\hline $\begin{array}{c}\text { Age } \\
\text { (days) }\end{array}$ & Type & $n$ & Mean & Range & Mean daily gain & \multicolumn{2}{c}{ Mean $K_{(b)}$ since } \\
\hline day 0 day 1
\end{tabular}




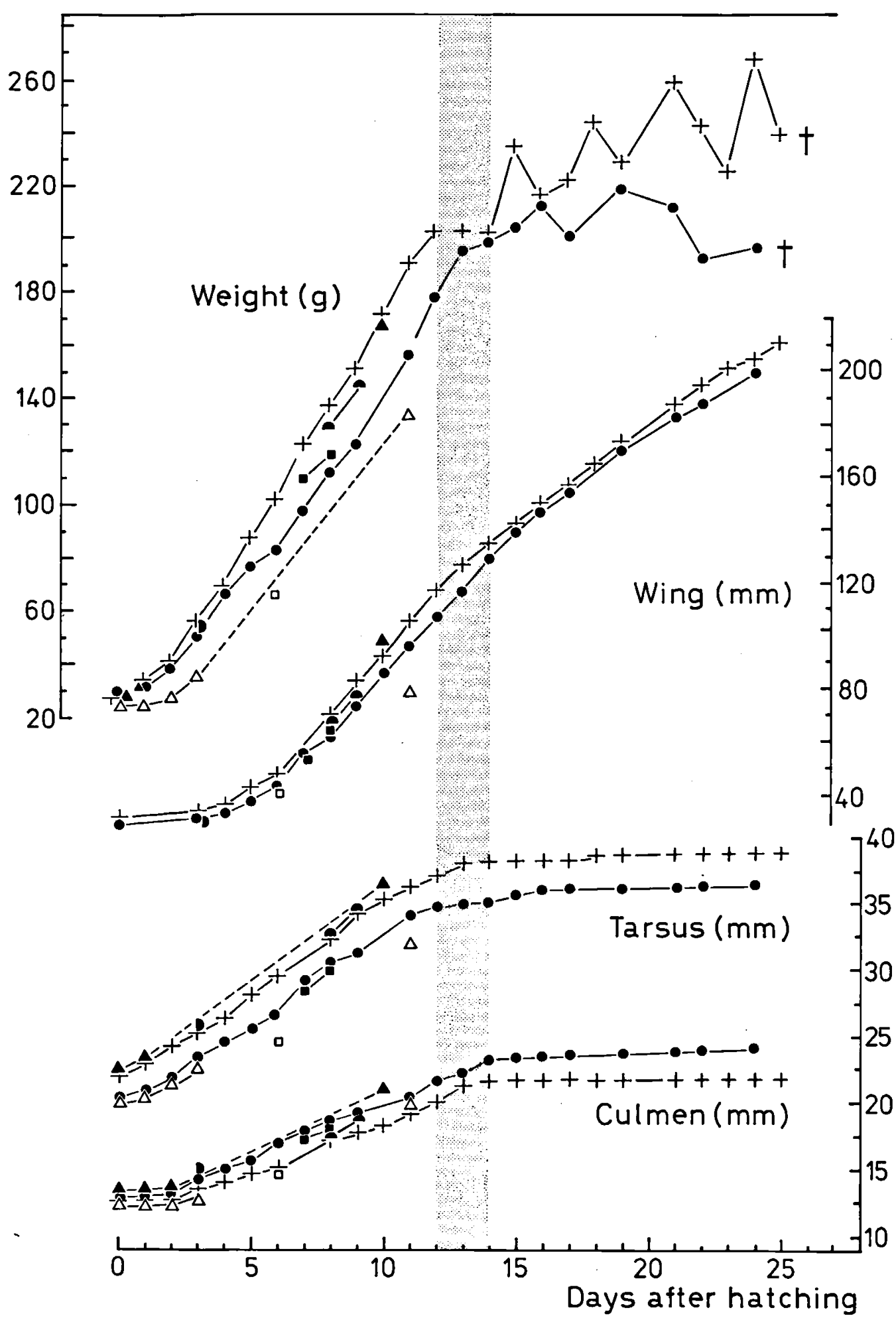

Fig. 4. Weights and measurements of eight chicks at Kærelv 1975, including those depicted in fig. 3, in relation to age; + indicates penned single chick; $\bullet-$ indicate free single chicks; $\Delta \boldsymbol{\nabla}$ indicate senior sibling chicks; $\Delta \square$ indicate junior sibling chicks; $\uparrow$ indicates day of death. 
with down, collected on the breeding grounds in Northeast Greenland on 17 August (ZMK 46.293), had a wing of $258 \mathrm{~mm}$, which, allowing for a minimum shrinkage of $1.2 \%$ (Barth, 1964), corresponds with a fresh length of 261 $\mathrm{mm}$, and a fledged juvenile of 26 August (ZMK 46.971 ), with a corrected wing length of 284 $\mathrm{mm}$, are estimated to have hatched on 12 and 10 July respectively.

Rapid growth of tarsus started at day 0 and continued until day 12 (fig. 4). Linear regression of length on date in this period resulted in $L_{t}=21.3+1.3 t(\mathrm{~mm})$ where $t$ is chick age in days after hatching. From day 14 to day 24 length increased with a mean of $0.07 \mathrm{~mm}$ per day.

Rapid growth of culmen started at day 2 and continued until day 13 (fig. 4). Linear regression of length (in $\mathrm{mm}$ ) on date in this period resulted in $L_{t}=13.3+0.77(t-2)$ where $t$ is chick age in days after hatching. From day 14 to day 24 , length increased with a mean of $0.05 \mathrm{~mm}$ per day.

\subsection{Chick and parental behaviour}

The incubation time for the Long-tailed Skua is about 24 days (Manniche, 1910; Salomonsen, 1950; Andersson, 1976a; Hansen, 1982). During this period male and female both incubated but the female usually attended a greater part of the time $(61 \%)$ than did the male which was more active in territorial defence (De Korte, 1985). The hatching process from pipping to the chick coming out of the shell takes one to two days, during which it was mainly the female which incubated $(80 \%$ of 15 random observations). After hatching the chicks were continuously brooded during the first two days mainly by the female $(75 \%$ of 16 random observations). Thereafter the chicks were brooded progressively less frequently and mainly during the night, which is not dark but relatively cool at this latitude. During cold weather a five day old single chick was still being covered by one of the parents.

After hatching the chicks remained in the nest for one or two days. Thereafter they moved around and sheltered in the vegetation among the hummocks. On the third day a single young had moved $200 \mathrm{~m}$ from the nest. On the fifth day the oldest of a twin had moved $300 \mathrm{~m}$, while its younger sibling (third day) was still near the nest. Two days later they both were about 500 $\mathrm{m}$ from the nest and $100 \mathrm{~m}$ apart. In general the female was closer to the young than the male during the whole fledging period (in $91 \%$ of 61 random observations of eight pairs the female was closest, excluding the continuous observation of the enclosed young during a 26 hour period, see below). However, in general the female did not show more aggression toward us when we approached the young than did the male. Observations of eight pairs with young showed that in two pairs the female was clearly the most aggressive, and in one pair the male. In the other five pairs male and female did not show clear differences in attack tendency. Observations of 15 nests with eggs earlier in the season in 1975, and at Kap Stewart in 1973 revealed about the same pattern (females most aggressive in three, males in two, about equal aggression in ten pairs). Variation in aggression of different pairs was great. A certain pair could attack vigorously, while the birds of another pair could continue to forage on the tundra when we handled the young. Generally, a tranquil bird had a tranquil partner and an aggressive bird an aggressive partner. Chicks of quiet partners were also relatively quiet and chicks of aggressive parents were very restless and defended themselves vigorously.

During a continuous 26 hour watch of the enclosed chick and its parents 22 to 23 days after hatching we noted that the most active 12 hour period (the young was considered to be active when standing or walking) was from 05.00 hours to 17.00 hours, the most active 6 hour period from 09.00 to 15.00 hours (33\% of the time active), and the least active 6 hour period from 23.00 to 5.00 hours ( $1 \%$ of the time active). Activities of the young in this period included flying exercises ( $1 \%$ of the total time), which could last for about a minute. In its flying exercises the young was standing or jumping and extensively flapping its wings. The female 
was usually standing or foraging within a few hundred metres from the young and was never seen to leave the territory, whereas the male, which brought food more frequently than the female, usually foraged in the outer parts of the territory and sometimes left it for a while. Activities mainly associated with feeding habits will be treated elsewhere (De Korte, in prep.)

\subsection{Potential predators}

Arctic Foxes entering a Long-tailed Skua territory were incessantly mobbed bỳ both male and female. This could last for up to half an hour in the breeding period (De Korte, 1985). The foxes were hampered by the attacks and snapped at the birds but usually continued to make loops through the territory. Foxes that were killed on 4 July $1973,14,17$ and 29 June, 1 and 5 July 1975 (weights of two males: 3050, $3440 \mathrm{~g}$; weights of four females $2600-2750 \mathrm{~g}$ ) all had remains of eggs in their stomachs, some of which could be identified as eggs of waders (Ringed Plover, Charadrius hiaticula, and Sanderling, Calidris alba).

In 1973 foxes were seen almost every day when we were in the census area at Kap Stewart in June and July. There was a litter with two young in that area and one more with three young within a distance of $500 \mathrm{~m}$ from the outer limit of the census area.

In 1974 and 1975 foxes were seen about every other day in June and July when we were in the census areas at Kap Stewart and Kærelv, respectively, but no occupied dens were found, whereas in 1979 in the Kærelv area a pair had young.

The Ermine, Mustela erminea, in Northeast Greenland subsists almost exclusively on lemmings (Pedersen, 1926, 1930; Elton, 1965; Vibe, 1985 in lit.). A male was caught on 28 June 1975 at Kærelv (weight 221 g). Egg remains found in its stomach could not be identified. In 1979 a brood of this animal was found at Kærelv (Hansen, 1984).

When Ravens, Corvus corax, were crossing a Long-tailed Skua territory they were attacked by both members of the pair, which always resulted in a quick withdrawal of the Raven. Of two Ravens collected at Kærelv on 17 July, one had eggs in its stomach, one of which could be attributed to Ringed Plover.

Gyrfalcons, Falco rusticolus, flying over a territory were also attacked by the Long-tailed Skuas, sometimes assisted by the neighbouring pair. The falcons hardly changed direction and continued their flight.

Glaucous Gulls, Larus hyperboreus, were at times seen near Long-tailed Skua territories along the coast and were easily driven away by the Long-tailed Skuas.

Arctic Skuas, Stercorarius parasiticus, and other Long-tailed Skuas were chased until they withdrew. At one point we handled one bird of a breeding pair while the other was pursuing a trespassing Long-tailed Skua. A fourth bird of this species then alighted at the nest, and started to peck at the eggs (we prevented damage by interfering quickly).

I do not have indications of overt aggression of siblings towards each other as has been reported by Taylor (1974) for the Long-tailed Skua and by Reid (1966) and Hemmings (1984) for the South Polar Skua, Catharacta maccormicki.

Man in Scoresby Sund is a potential predator as the local people shoot a number of Longtailed Skuas along the ice edge in May, June and July for dog food. One of the 27 adults ringed by us in 1975 at Kærelv was shot in June 1977 by a Greenlandic hunter.

\section{DISCUSSION}

Breeding success in 1973, 1974, 1975 and 1979 was low. In 1973 and 1974 no young hatched in the study areas, and in the whole Scoresby Sund district and other parts of Northeast Greenland no or very few young fledged (Ferns \& Mudge, 1976; Hjort, 1976; Meltofte, 1976; Green \& Greenwood, 1978). In 1975 and 1979 young hatched and though none fledged in the study areas, some did in other parts of the Scoresby Sund region (Hansen, 1982, 1984) and probably also in other parts of Northeast Greenland (Meltofte, 1977; Blomquist \& 
Elander, 1982 in lit.). The questions are to which mortality factors this low breeding success can be attributed, under which circumstances the Long-tailed Skuas will be able to have a good breeding success, and how they will be able to maintain a more or less stable territorial population?

\subsection{Growth of body mass and appendages}

Ricklefs (1968) showed that growth rate in altricial landbirds (passerines and raptorial birds) can be predicted from asymptotic weight. The value for the growth rate $k$ derived from the logistic equation for my field data on the Long-tailed Skua (0.232) was the same as the predicted value for raptorial birds of its size. Converted to a Gompertz equation at inflection point (see Ricklefs, 1973) this growth rate was 0.158 which was similar to that predicted for semi-precocial two-egg laying birds of its size (cf. Ricklefs, 1973). Mean relative instantaneous growth rates for the first eight days for chicks in Canada (20.1) and Alaska (22.6) calculated by Maher $(1970,1974)$ were higher than the values found by us (table IV), thus it is clear that growth rates in Long-tailed Skuas can be higher than the predicted values for altricial as well as semi-precocial birds of its size. The South Polar Skua and the Great Skua, Catharacta skua, had Gompertz growth rates of 0.092 and 0.112 , respectively (derived from Reid, 1966 and Furness, 1983) which is intermediate between raptors and semi-precocial two-egg laying gulls of their size (cf. Ricklefs, 1973). The relatively high growth rate in the Long-tailed Skua shortens the pre-fledging period, which is an important adaptation for the short breeding season in the High Arctic. According to Lack (1954), Nice (1957) and Wijnandts (1984) it can be argued that an important aim of high growth rate is also to minimize the risk of predation to which the Long-tailed Skua chicks may be severely exposed. The South Polar Skua and the Great Skua, though exposed to conspecific predation (Spellerberg, 1971; Furness, 1984) suffer much less from predation and their growth rates are not higher than expected.
At hatching, tarsus and culmen were relatively more developed and these appendages reached asymptotic length much earlier than the wing (table $\mathrm{V}$, fig. 4). In reaching adult size tarsus and culmen increase about two-fold and the wing ten-fold. Only the tarsus grew fast right from hatching whereas culmen and wing grew very slowly during the first few days, a phenomenon also observed in the Great Skua (Furness, 1983). A few days before fledging, tarsus and culmen were still more developed than the wing, with the tarsus most advanced. Half-way the fledging period (assumed fledging 26 days after hatching, Andersson, 1976a), fast growth of both culmen and tarsus and fast weight gain stopped.

\section{TABLE V}

Weights (g) and measurements ( $\mathrm{mm}$ ) of chicks at day of hatching and a few days prior to fledging (values for adults after De Korte, 1985).

\begin{tabular}{lcrccl}
\hline \multirow{6}{*}{ Weight } & Age & $n$ & Mean & Range & $\begin{array}{c}\text { \% of } \\
\text { adult } \\
\text { mean }\end{array}$ \\
\hline \multirow{5}{*}{ Wing } & 0 & 7 & 26.5 & $25.0-29.5$ & 9.2 \\
& 24 & 2 & 232 & $196-266$ & 84 \\
& adult & 86 & 288 & $218-444$ & \\
Tarsus & 0 & 7 & 30 & $29-31$ & 9.7 \\
& 24 & 2 & 201 & $197-204$ & 65 \\
& adult & 87 & 309 & $293-334$ & \\
Culmen & 0 & 7 & 21.3 & $20.4-22.5$ & 50.4 \\
& 24 & 2 & 37.3 & $35.9-38.7$ & 88 \\
& adult & 89 & 42.2 & $38.4-45.4$ & \\
& 24 & 7 & 12.5 & $12.0-13.1$ & 44.8 \\
& adult & 89 & 22.6 & $21.6-23.5$ & 80 \\
\hline
\end{tabular}

O'Connor (1977) argued that differential growth rates displayed by various parts of the body are adaptive. The greater development of legs in small chicks suggests that mobility plays a particularly significant role in the first days after hatching. Small Long-tailed Skua chicks do not forage themselves but are exclusively fed by their parents and thus early mobility seems especially important to avoid predators (cf. Fuller, 1983).

Midway in the fledging period the beak has developed to such an extent that the chick is 
able to devour almost the largest prey items that the parents were able to swallow, which saves time in feeding the chick.

\subsection{Mortality factors}

\section{Food shortage and inclement weather}

Complete non-breeding in 1974 was due to a drastic decrease in body energy reserves of paired birds during the pre-breeding period (first half of June). This can wholly be attributed to poor food availability on the tundra in that season (De Korte, 1985, and in prep.).

The calculated mean number of eggs per territorial pair in 1973 and 1975 were similar (table I). Similar mean clutch biomass per breeding pair (table I), similar body energy reserves of breeding birds in the same phase of breeding in both years (De Korte, 1985), and similar Arctic Fox catches in the respective succeeding years (fig. 5 B) all indicate a similar availability of food per pair in 1973 and 1975 . In 1979 all these values were much higher than in 1973 and 1975, which indicate a much better food availability in 1979 . When we use the number of fox furs from Scoresbysund purchased in the succeeding years as an index for lemming and hence food availability, this index shows no correlation with survival time of eggs (table II, fig. $5 \mathrm{~A}$ ) and we may conclude that differences in food availability in those years were not responsible for the differences in hatching success.

Virtually all birds, caught during incubation in those years, had energy reserves well above the level at which food searching for self maintenance becomes the most important of all activities (De Korte, 1985). The exception was an inexperienced female in 1975, approaching the critical level (energy reserves $25 \%$ of structural size) in the days just prior to hatching. A pair deserting its egg after nine days in 1975 had energy reserves similar to birds continuing incubation. We can conclude that the low hatching success was not due to food shortage in those years.

Growth rate $K_{(b)}$ in our single and senior sibling chicks for the first seven days ranged from 17.0 to 22.3. In Alaska and Canada it ranged from 19.4 to 24.3 in years of food richness (Maher, 1970, 1974). These growth rates and a comparison of the weights presented in table VI suggest that in the first two weeks of life, our chicks in general gained weight somewhat more slowly than chicks in years with plenty of food and high fledging success but faster than chicks in a rather poor food situation, like in Lapland in 1973, with moderate fledging success and some parents deserting eggs and young due to scarcity of food (Andersson, 1976a).

Energy reserves of parents in the first nine days after hatching in 1975 did not decrease and remained above the level at which food searching for self maintenance becomes the most important activity. These data indicate that mortality caused by food shortage was unlikely in the first two weeks of life.

At the end of the second week fast weight gain stopped quite abruptly, which coincided with the end of the fast growth period of tarsus and culmen, while the wing continued to grow fast (fig. 4). The free chick had a smaller structural size (indicated by length of wing and

TABLE VI

Weights (g) of single and senior sibling chicks and junior sibling chicks at an age of 9 and 11 days in different areas and years. Sources: (1) Maher, 1974; (2) Andersson, 1976a; (3) present study.

\begin{tabular}{|c|c|c|c|c|c|c|c|c|c|c|c|}
\hline & & \multicolumn{4}{|c|}{ Single + Senior Chicks } & \multicolumn{4}{|c|}{ Junior Chicks } & \multirow{2}{*}{$\begin{array}{l}\text { Fledging } \\
\text { success }\end{array}$} & \multirow[t]{2}{*}{ Sources } \\
\hline & & $n$ & 9 days & $n$ & 11 days & $\bar{n}$ & 9 days & $n$ & 11 days & & \\
\hline Alaska & 1959 & 2 & $172(170-173)$ & 2 & $208(206-210)$ & & & & & high & 1 \\
\hline Lapland & 1973 & 3 & $96(86-107)$ & 2 & $138(127-149)$ & 1 & 88 & 1 & 110 & moderate & 2 \\
\hline $\begin{array}{l}\text { Lapland } \\
\text { Scoresby }\end{array}$ & 1974 & 1 & 147 & 1 & 172 & 2 & $133(127-149)$ & 2 & $172(156-180)$ & high & 2 \\
\hline Sund & 1975 & 3 & $139(122-151)$ & 2 & $174(157-190)$ & 1 & 115 & 1 & 134 & low & 3 \\
\hline
\end{tabular}


tarsus, De Korte, 1985) than the fenced chick. Using the method described by De Korte (1985) it appeared that in the first week of life the condition index ratio of free chick/fenced chick was 1.09 , in the last week it was 0.93 which indicates a slightly poorer condition in the free chick in the third and fourth week when it did not gain weight anymore. As the age difference of the two chicks was three days (fig. 3) the effect of difference in growing period can be ruled out as a responsible factor (cf. Birkhead \& Nettleship, 1982, 1984). The fenced chick was taken by an Arctic Fox some days before fledging (fledging age 25-28 days, Maher, 1970, 1974; Andersson, 1976a). All chicks did well when seen for the last time and there were no indications that single chicks and senior sibling chicks died of food shortage. Junior siblings were smaller than their senior mates at the same age (fig. 4) and may have starved to death. Manniche (1910), Savile \& Oliver (1964) and Maher (1970) reported a general failure of younger chicks to survive more than two weeks. However, in a year of a very great food supply some of them may fledge (Taylor, 1974; Andersson, 1976a).

The causes of mortality in the four young that were not seen after a few days after hatching in 1979 are unknown. As food was very plentiful that year (Hansen, 1984) food shortage can be ruled out as the cause of their death.

Hatchlings of the semi-precocial Long-tailed Skua are very vulnerable to adverse weather during the first days after hatching when they are unable to thermoregulate adequately (LeCroy \& Collins, 1972; Ricklefs, 1983). Wind with rain and wet snow occurred three times in July 1975 (fig. 3). During a day with such circumstances both chicks (one and two days old) of a pair of siblings died. Their yolk reserves indicated that they did not die of starvation. Stercorariidae generally hatch with a yolk reserve adequate to sustain them for up to three days (Reid, 1966). The oldest member (age 1 day) of another pair of siblings and its unhatched mate (1 day before hatching), a single young of 2 days old and one of 5 days old, survived the same cold day, being continuously brooded by one of the parents. The same day a large fraction of the population of one and two day old chicks in a nearby colony of Arctic Terns, Sterna paradisaea, died. Long-tailed Skua young of 11, $14,17,19$ and 22 days old survived days with similar adverse weather without being brooded. During these days a temporary stagnation of weight gain in chicks older than four days was apparent (figs. $3 \& 4$ ), indicating that they had to withstand a fast of some time. Adverse weather, which occurred when the six disappeared young were $4,7,9,10,11$ and 13 days old, respectively, may have killed the two youngest ones but in all probability not the others.

\section{Predators}

It seems that a pair of Long-tailed Skuas manages to drive away all potential predators, except for the Arctic Fox. Maybe the Ermine is a threat too but it is unlikely that this small predator regularly challenges a pair of Longtailed Skuas which are able to kill it. Parmelee \& MacDonald (1960) report predation of Gyrfalcons on recently fledged young of Longtailed Skuas but not on eggs and chicks. Probably virtually all predation of Long-tailed Skua eggs is done or caused by foxes. In one case a chick of 25 days was taken from the enclosure by a fox, judging from scratches, where a fox had dug itself into it. Other authors present evidence that foxes frequently take Long-tailed Skua eggs and young (Maher, 1970, 1974; Taylor, 1974; Meltofte et al., 1981). Warding off foxes has adverse effects on breeding success, not only by expenditure of energy, but likewise because the adults must leave the eggs or young exposed to other predators and exposed to the elements (cf. Kampp, 1982). In this respect one is led to ask the question whether different pairs of Long-tailed Skuas show different intensity of aggression towards foxes as was the case towards man. A strategy of relatively low-level aggression has the advantage that the adult sits longer on the nest, thus chilling periods are shorter, and the predators attention is not readily directed to the nest area. 
On the other hand, incessantly being mobbed will be a nuisance to the predator when searching for eggs and chicks. Linear regression of survival time of clutches on number of fox furs from the same year yield a negative regression coefficient, significantly different from zero (fig. $5 \mathrm{~B} ; T_{f}=23.8-0.20 f, n=28, r^{2}=0.79$ ).

Fox predation of eggs of ground-nesting birds is often especially pronounced the year after a rodent peak when rodents are scarce and foxes are relatively numerous (Meltofte et al., 1981). However, predation may also be severe two years after such a peak in a year in which overall food production on the tundra is very low as was the case in 1974 when with a moderate number of foxes, nests of waders were still severely predated (fig. 5 , data on wader nests after De Korte, 1975; De Korte et al., 1981; Hansen, undated). Similarly in the second of two consecutive years of lemming abun- dance, predation may be heavy when during part of the incubation period a minor part of the ground is snow-free and the numerous foxes on the snow-free patches will easily find nests (Meltofte et al., 1981). Extensive snow cover in the breeding period in general will make the foxes concentrate on the snow-free areas where the birds nest (Byrkjedal, 1980). The very low survival rate for Long-tailed Skua nests in 1973 undoubtedly has been affected in this sense by the rather late disappearing snow (fig. $5 \mathrm{C}$ ). The date for comparison (10 June) in fig. $5 \mathrm{C}$ is the mean of the estimated dates at which $50 \%$ of the breeding pairs of Long-tailed Skuas had started egg-laying (Kap Stewart 1973, 12 June; Kærelv 1975, 10 June; Kærelv 1979, 9 June). In waders late thawing snow similarly increased predation (fig. 5). However they did not lose all clutches, not even in 1974 when, due to the very late disappearance of snow and the very
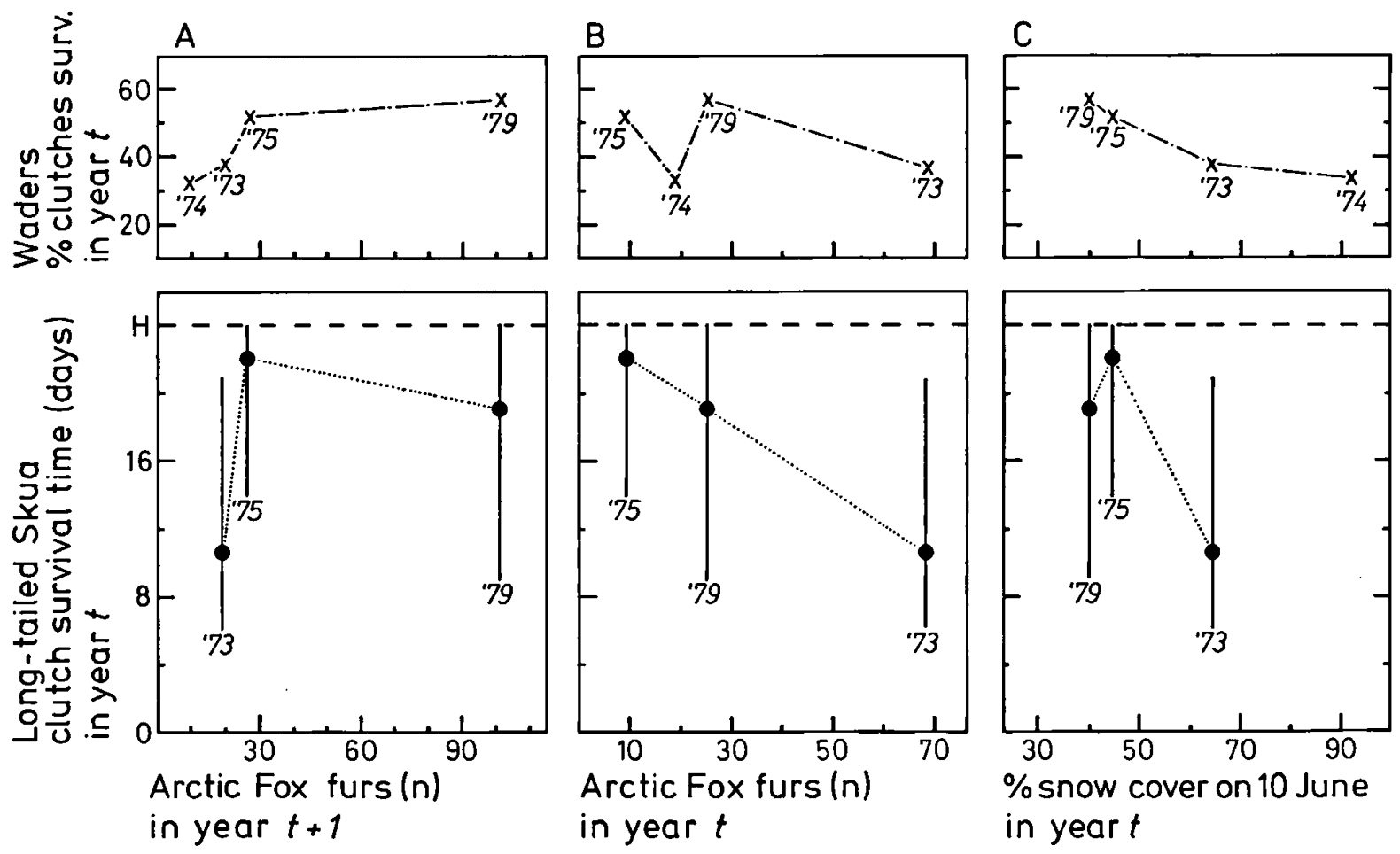

Fig. 5. Mean survival time (๑) and range of survival time (vertical) of Long-tailed Skua clutches found $(1973, n=$ $6 ; 1975, n=14 ; 1979, n=8)$ and percentage of wader clutches found surviving to hatching $(x)$ in different years in relation to fox furs purchased in Scoresbysund in the following year = food availability index (A), in relation to fox furs in the same year $=$ predation index $(B)$, and in relation to percentage snow cover on the tundra on $10 \mathrm{June}=$ index of predation effort of one fox per unit of snow-free area (C); H = hatching on day 24. Data for 1979 computed after Hansen (undated, in lit., 1982). 
poor food availability, predation was more severe than in 1973.

Of the ten young hatched at Kærelv in 1975 probably five to eight were taken by foxes. This means that 60 to $75 \%$ of total offspring mortality was caused by fox predation. In 1979 at Kærelv about $70 \%$ of total offspring mortality was due to predation.

One may wonder whether the observers' activities have had a significantly negative effect on breeding success. In 1975 at Kærelv one 2egg clutch did not hatch possibly partly due to our activities in the days prior to hatching. In 1979 one 2-egg clutch was accidently destroyed. Other negative effects are more difficult to trace. Walking through the territories, catching the breeding birds, weighing the eggs, searching and handling the young are all activities which put a strain on the birds they would not have to endure in a year without observers. An important question in this respect is whether we have guided foxes to the nests we visited. When observing foxes searching the tundra we never got the impression that they trotted in rather straight lines, indicating a kind of trail that they followed, but rather in loops which were followed back and forth. In 1973, 1974 and 1975, in areas with territorial Long-tailed Skuas, where we had not or rarely been in the incubation period and early young rearing period, no young birds were seen later in summer. However in 1979 one juvenile of the year was seen away from the study area. Probably our activities did influence breeding success negatively only to a minor extent. Without observers possibly a few young would have fledged at Kærelv in 1975 and 1979.

Fox predation on the tundra at Scoresby Sund in spring and summer may be greater than farther to the north in Northeast Greenland. Scoresby Sund is relatively rich in seabirds, seals and small whales and is the only area in Northeast Greenland with a human hunting community (Pedersen, 1926, 1930; Vibe, 1967; Born, 1983, 1984). In late summer most foxes from the tundra turn to the coast (Pedersen, 1926, 1930), where they benefit from a rich food source, including remains left by the Greenlandic hunters. In winter they hunt extensively on Muskoxen, Ovibus muschatus (pers. comm. local people 1973, 1974, 1975; Thing et al., 1984); the remains provide the foxes with food. These additional food sources will widen the bottleneck of food scarcity in winter time, so the fox population can survive this critical period better than in areas where this extra food is not available.

\subsection{Adult mortality and recruitment}

Members of the family Stercorariidae have a long life expectancy; one male Arctic Skua was recorded attempting to breed for over 30 summers (Venables \& Venables, 1955). Great Skuas have an adult survival rate of $91-93 \%$ (Burton, 1968; Furness, 1978). The number of territorial pairs at Kærelv declined with $37 \%$ from 1975 to 1979 (table I). It has been proved that Longtailed Skuas show strong site tenacity which is not reduced even in response to non-breeding years (Maher, 1970; Taylor, 1974; Andersson, 1976a, 1981; De Korte, 1977, 1984; Hansen, 1982). As snow conditions in the period of territory establishment (see below) in both years were similar and quite favourable, and food availability in the last year was better, the population decline can only be explained by failing recruitment. In 1973, 1974 and 1975 young had fledged neither in this area nor in the surrounding region and for 1976 it is unlikely that any fledged (Hansen, 1982). Moreover, as Long-tailed Skuas reach sexual maturity after their third or fourth calendar year (De Korte, 1985) only part of that number of young from 1976 would have been incorporated in the 1979 population. With the assumption that $63 \%$ of the adult Long-tailed Skuas at Kærelv survived four years we arrive at an adult annual survival rate of $89 \%$, which is probably lower than elsewhere within the breeding range because at Scoresby Sund there is some human hunting pressure. If the annual survival rate of juvenile Long-tailed Skuas is $85 \%$ three to four years up to first breeding (Andersson, 1976a) then 52 to $61 \%$ of successful fledglings will survive until they start to breed. Thus a pair of 
Long-tailed Skuas would need to successfully raise during its whole life three to four chicks in order to maintain a stable population. Given that they attempt to breed for twelve seasons this would mean one chick every three to four years on average. All breeding areas which have been surveyed in a few consecutive years (table VII) show a number of years without production of fledglings alternated with a year with production. At Bathurst Island in four consecutive years a total of 0.2 fledglings per territorial pair were produced (according to Taylor, 1974); at Ellesmere a total of 1.3 in six consecutive years (Maher, 1970); in Lapland a total of 3.3 in seven consecutive years (Andersson, 1976a). It is clear that we did not witness a rich year, which does not occur frequently but which is essential for maintaining a stable population. The possibility that at Scoresby Sund, which is at the southern edge of the breeding distribution of the Long-tailed Skua in Northeast Greenland (De Korte, 1977), there is a netto influx of birds originating from more productive areas to the north (see below) deserves consideration.

\subsection{Densities}

In different areas in the same year and in the same area in different years territorial pair density could differ considerably (table I). For 1973, 1974 and 1975 the maximum of territorial pair density in a given area was significantly and negatively correlated with percentage of the tundra covered by snow on 10 June (fig. $6, D=$ pairs per $\mathrm{km}^{2}=0.92-0.0075$ $\times \%$ snow cover on 10 June, $n=6, r^{2}=0.97$ ). In this equation Kærelv 1979 has been left out because of the population drop apparently caused by failing recruitment in the preceding years (see above). When we compare Kap Stewart 1973 and 1974 we may conclude that Long-tailed Skuas, notwithstanding their strong site tenacity, refrain from establishing a territory if snow cover in their area is very extensive and extremely long lasting.

Estimated breeding densities in Scoresby Sund fluctuated from 0 to 0.8 pairs per $\mathrm{km}^{2}$

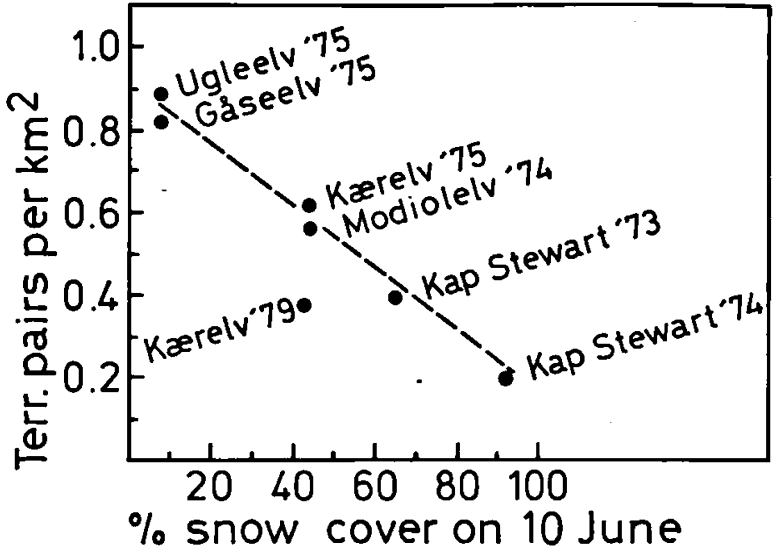

Fig. 6. Territorial pair density in relation to percentage of the tundra covered with snow on 10 June at Scoresby Sund in different areas and years. Kærelv 1979 is exceptional because of the apparent recruitment failure after 1975.

(table I). The fraction of the number of territorial birds which did breed was either $0 \%$ (1974) or $88-92 \%(1973,1975,1979)$. Data given by Schaanning (1916), by Taylor (1974) and by Meltofte et al. (1981) support the assumption that in years with moderate and good food availability about $90 \%$ of the territorial population starts breeding.

Data about densities of Long-tailed Skuas in different areas in Northeast Greenland and elsewhere are presented in table VII. For some areas the breeding densities given are probably too low because observers did not take into account the predation they probably had missed. Therefore, to provide a comparable value, the maximum breeding density directly observed at Scoresby Sund (0.6) is given, and not the calculated value $(0.9)$. When the authors referred to in table VII only gave breeding densities I assumed that in those cases $90 \%$ of territorial pairs had laid eggs.

It appears that in suitable habitats in the High Arctic (excluding the extreme desert-like Southern Peary Land) territorial pair density (mean 1.0, range 0.6-1.6) is higher than in the Low Arctic (mean 0.5, range 0.2-0.8), where the tundra becomes snow-free later than more northward (Salomonsen, 1972). In Northeast Greenland there is a tendency of increasing 


\section{TABLE VII}

Estimated maximal territorial pair density and observed maximal breeding pair density in different High-Arctic and Low-Arctic regions (delimitation after Salomonsen, 1972). Sources: (1) this paper; (2) Hall, 1966; Hall \& Waddington, 1966; Green \& Greenwood, 1978; Newton, 1984 in lit.; (3) Blomquist \& Elander, 1982 in lit.; (4) Rosenberg et al., 1970; (5) Meltofte et al., 1981; (6) Manniche, 1910; Meltofte, 1975; (7) Johnsen, 1953; Røen, 1965; Just, 1967; Andersen, 1970; Meltofte, 1976; Håkansson et al., 1981; (8) Maher, 1970; (9) Taylor, 1974; (10) Manning et al., 1956; (11) Maher, 1974; (12) Kampp, 1982; (13) Parmelee et al., 1967; (14) Andersson, 1973; (15) Portenko, 1973; (16) Krechmar, 1966; (17) Schaanning, 1916; (18) Andersson, 1976 a.

\begin{tabular}{|c|c|c|c|c|c|c|}
\hline Area & & $\begin{array}{l}\text { Latitude } \\
{ }^{\circ} \mathrm{N}\end{array}$ & $\begin{array}{c}\text { Seasons } \\
(n)\end{array}$ & $\begin{array}{c}\text { Terr. pairs } \\
\text { per } \text { km² }^{2} \\
\text { (estim. max.) }\end{array}$ & $\begin{array}{l}\text { Breed. pairs } \\
\text { per km² } \\
\text { (obs. max.) }\end{array}$ & Sources \\
\hline \multicolumn{7}{|l|}{ High Arctic } \\
\hline Scoresby Sund & NE.Gr. & $(70-71)$ & 4 & 0.9 & 0.6 & 1 \\
\hline Scoresby Land & NE.Gr. & $(71-72)$ & 3 & 0.5 & 0.3 & 2 \\
\hline Mackenzie Bugt & NE.Gr. & $(73-74)$ & 1 & 1.1 & 1.0 & 3 \\
\hline Wollaston Forland & NE.Gr. & $(74-75)$ & 1 & 1.6 & & 4 \\
\hline Hochstetter Forland & NE.Gr. & $(75-76)$ & 1 & 0.8 & 0.7 & 5 \\
\hline Germania Land & NE.Gr. & $(76-77)$ & 3 & 1.6 & 1.5 & 6 \\
\hline South Peary Land & NE.Gr. & $(82-83)$ & 8 & 0.1 & 0 & 7 \\
\hline Ellesmere Island & Can. & $(81-82)$ & 6 & 0.9 & 0.8 & 8 \\
\hline Bathurst Island & Can. & $(75-76)$ & 4 & 0.6 & 0.5 & 9 \\
\hline Banks Island & Can. & $(71-72)$ & 3 & 0.6 & & 10 \\
\hline Northern Alaska & & $(70-71)$ & 4 & 1.0 & 0.9 & 11 \\
\hline \multicolumn{7}{|l|}{ Low Arctic } \\
\hline Disko Bugt & W.Gr. & $(68-69)$ & 1 & 0.5 & 0.5 & 12 \\
\hline Victoria Island & Can. & $(69-70)$ & 3 & 0.2 & 0.2 & 13 \\
\hline Nuvagapak Point & $\mathrm{Al}$. & $(69-70)$ & 1 & 0.8 & & 14 \\
\hline Chukotsk Pen. & Sib. & $(66-67)$ & 3 & 0.2 & 0.2 & 15 \\
\hline Taimyr Pen. & Sib. & $(72-73)$ & 4 & 0.5 & & 16 \\
\hline Novaja Semlja & Sib. & $(73-74)$ & 2 & 0.7 & 0.6 & 17 \\
\hline Lapland & Sw. & $(68-69)$ & 9 & 0.7 & 0.6 & 18 \\
\hline
\end{tabular}

densities from Scoresby Sund to Germania Land (cf. Pedersen, 1934), which more or less runs parallel with the density pattern of waders discussed by Meltofte (1985). Meltofte argued that High-Arctic waders reached highest densities in places with the largest snow-free vegetated areas in the first half of June. From Scoresby Sund to Southern Peary Land snow disappears progressively earlier in spring whereas the vegetation cover progressively decreases, resulting in optimal conditions in central Northeast Greenland and marginal areas in southern Scoresby Sund with longlasting snow cover and in Southern Peary
Land, where large areas are devoid of vegetation. The densities of the Long-tailed Skua given for central Northeast Greenland are the highest recorded anywhere in its breeding range, which indicates that the Long-tailed Skua is adapted to High-Arctic rather than to Low-Arctic conditions.

\subsection{Conclusions}

Territorial pair density in 1973, 1974 and 1975 was negatively correlated with the percentage snow cover on the tundra in the first half of June. Population decline in 1979 was probably 
caused by failing recruitment of new breeders in the intervening years.

Complete hatching failure in 1973 was due to predation by the Arctic Foxes. Foxes were relatively numerous that year and, because of the rather extensive snow cover during the breeding period, their potential searching area, which included snow-free areas only, was relatively small. Non-breeding in all pairs in 1974 was due to food shortage on the tundra. Low hatching success and no fledging success in 1975 and 1979 was mainly due to predation by and presence of Arctic Foxes and to a minor extent to addled and deserted eggs, to inclement weather and to the overall effect of observers.

Laying of eggs depended on availability of food in the pre-breeding period. In this period about $90 \%$ of all territorial birds initiated breeding and if the female maintained more than $75 \%$ of the body energy reserves at arrival, eggs were laid. Thus breeding is a direct outcome of good food availability resulting in maintained body energy reserves of breeding adults. Once eggs had been laid food availability played a lesser role influencing breeding success. At this time fox predation was the most important factor. Loss of eggs due to predation is clearly correlated with the total effort of foxes per snow-free unit of area. This means the smaller the snow-free area the higher the chances are of nest destruction by foxes, although food availability may play an indirect role, in offering a larger and easier accessible range of prey other than eggs. Searching image phenomena may also play a little role.

Growth rate was relatively fast for a semiprecocial bird of this size and is, just like the early development of the legs, one of the means to help avoid predation.

High breeding success of the Long-tailed Skua in Northeast Greenland will occur only in years with moderate to high food richness on the tundra combined with a rather early disappearance of snow cover and a relatively low number of Arctic Foxes. Any other combination of these three factors will result in lower breeding success. When on average a Longtailed Skua produces in its life two successful fledglings, the population will probably not decline.

\subsection{Robustness of conclusions and perspective}

The conclusions put forward in this paper are based on relatively few data and several estimates and assumptions. For instance, all 1egg clutches found are supposed to be complete clutches, whereas it is possible that some of them were second-laid eggs of a 2-egg clutch of which the first-laid egg was predated prior to clutch completion. In calculating mean egg production per territorial pair, it was supposed that predation on 1-egg and 2-egg clutches was similar though there were indications that the former were more exposed to predation than the latter (cf. Furness, 1984). Other variables: laying date, egg size, breeding density, and experience of the pair were also not taken into account because of the scarcity of available data. The indices of food availability and predation are based on a relatively small number of fox furs and the question may arise whether the number of furs reflect trapping activities rather than food supply in the preceding summer. Because of declining fur prices from 1975 to 1980 and because income from fox furs plays a minor role in the economy of the Greenlandic hunters (pers. comm. local people 1975) it is unlikely that in 1980 there was a greater catching effort; the catch however was 11-fold compared with 1975.

It has to be accepted that in a study of breeding success of the Long-tailed Skua one has to cope with low territorial pair densities and hence low breeding pair densities. This is the reason that a team of two persons will not be able to follow systematically more than 10 or 20 pairs in the course of the breeding season. Heavy predation which results in a nil hatching and fledging success may make one doubt whether methodological failures were made during fieldwork. To check this possibility one should choose a study area for intense study and a similar area, where interference is reduced to one visit every two or three weeks, as a control. Local circumstances (e.g. snow cover) may dif- 
fer considerably within relatively short distance. So two teams working in the same season in different areas, would greatly enhance the output of a study. We did not see any fledglings during all seasons. If any juveniles had fledged, capturing them as I did with Arctic Tern juveniles, using a fowlers's net (fleyg), measurements of growth and weight could have been continued in the first week after fledging. Long-term population studies are urgently required to assess how the species maintains itself in such a hostile environment.

\section{ACKNOWLEDGEMENTS}

I am much indebted to Dr. J. Wattel (Amsterdam), Prof. Dr. R. H. Drent (Groningen) and J. Walters (Amsterdam) for stimulating discussion and advice when preparing the first draft of the manuscript. I wish to thank Prof. Dr. K. H. Voous (Huizen), J. A. van Franeker (Amsterdam) and $\mathbf{H}$. Meltofte (Copenhagen) for critically reading the manuscript. A. Ameling (Amsterdam) helped with translating Russian publications. D. M. Gottheil (Honolulu) and A. James (Amsterdam) kindly corrected the English.

\section{REFERENCES}

Andersen, O. G. N., 1970. Ornithologiske observationer på 5. Pearyland expedition sommeren 1968. Dansk orn. Foren. Tidsskr., 64: 104-112.

ANDERsson, M., 1971. Breeding behaviour of the Longtailed Skua Stercorarius longicaudus (Vieillot). Ornis Scand., 2 (1): 35-54.

- , 1973. Birds of Nuvagapak Point, Northeastern Alaska. Arctic, 26: 186-197.

- , 1976a. Population ecology of the Long-tailed Skua Stercorarius longicaudus Vieill. J. anim. Ecol., 45: 537-559.

- , 1976b. Clutch size in the Long-tailed Skua Stercorarius longicaudus: some field experiments. Ibis, 118: $586-588$.

-, 1981. Reproductive tactics of the Long-tailed Skua Stercorarius longicaudus. Oikos, 37: 287-294.

BArth, E. K., 1967. Standard body measurements in Larus argentatus, $L$. fuscus, $L$. canus, and $L$. marinus. Nytt Mag. Zool., 14: 7-83.

Birkhead, T. R. D. N. NetTleship, 1982. The adaptive significance of egg size and laying date in Thickbilled Murres Uria lomvia. Ecology, 63 (2): 300-306.

- \&- 1984 . Egg size, composition and offspring quality in some Alcidae (Aves: Charadriiformes). J. Zool., Lond., 202 (2): 177-193.

Born, E. W., 1983. Havpattedyr og havfugle i Scoresby Sund. Report Danmarks Biologiske Undersøgelser: 1-112.
-, 1984 . Et fangstsamfund i fokus. Naturens Verden, 1984 (5-6): 161-176.

BRODY, S., 1945. Bioenergetics and growth: 508 (Reinhold Publ. Co., New York).

Burton, R. W., 1968. Breeding biology of the Brown Skua Catharacta skua at Signy Island, South Orkney Islands. Bull. Br. Antarct. Surv., 15: 9-28.

ByrkJedal, I., 1980. Nest predation in relation to snowcover-a possible factor influencing the start of breeding in shorebirds. Ornis Scand., 11: 249-252.

Davis, J. W. F., 1975. Age, egg-size and breeding success in the Herring Gull Larus argentatus. Ibis, 117: 460-473.

Elton, C., 1965. Voles, mice and lemmings. Historiae Naturalis Classica, 22: 1-496 (Wheldon \& Wesley Ltd., New York).

Ferns, P. N. \& G. P. Mudge, 1976. Abundance and breeding success of birds in Ørsted Dal, East Greenland, 1974. Dansk orn. Foren. Tidsskr., 70: 21-33.

FULLER, R. J., 1983. The relative growth of bill, tarsus and wing of Lapwing Chicks in the Outer Hebrides. Ringing and Migration, 4: 139-144.

Furness, R. W., 1978. Migrations and survival rates of Great Skuas ringed in Scotland. Bird Study, 25: 229-238.

-, 1983 . Variations in size and growth of Great Skua Catharacta skua chicks in relation to adult age, hatching age, egg volume, brood size and hatching sequence. J. Zool., Lond., 199: 101-116.

- , 1984. Influences of adult age and experience, nest location, clutch size and laying sequence on the breeding success of the Great Skua Catharacta skua. J. Zool., Lond., 202: 565-576.

Furness, R. W. B. L. Furness, 1981. A technique for estimating the hatching dates of eggs of unknown laying date. Ibis, 123 (1): 98-103.

Green, G. H. J. J. D. Greenwood, 1978. Joint Biological Expedition to North East Greenland 1974: 1-258 (Dundee University Printing Unit).

Hall, A. B., 1966. The breeding birds of an East Greenland valley, 1962. Dansk orn. Foren. Tidsskr., 60: $175-185$.

Hall, A. B. R. N. Waddington, 1966. The breeding birds of Ørsted Dal, East Greenland, 1963. Dansk orn. Foren. Tidsskr., 60: 186-197.

Hansen, J. M., undated. Hurry Fjord Ekspeditionen 1979, avifaunistical survey: 1-42 (Naturhistorisk Museum Ảrhus).

-, 1982. The 1979 population of the long-tailed skua Stercorarius longicaudus at Kærelv, Scoresby Sund, East Greenland: 1-13. (Unpublished manuscript.)

- , 1984. The population of Long-tailed Skuas Stercorarius longicaudus at Kærelv, Scoresby Sund, East Greenland 1979. Dansk orn. Foren. Tidsskr., 78: 99-104.

Hemmings, A. D., 1984. Aspects of the breeding biology of McCormick's Skua Gatharacta maccormicki at 
Signy Island, South Orkney Islands. Br. Antarct. Surv. Bull., 65: 65-79.

HJorT, C., 1976. Notes on the birds of Hudson Land and Hold with Hope, Northeast Greenland, 1973. Dansk orn. Foren. Tidsskr., 70: 35-44.

Hussell, D. J. T., 1972. Factors affecting clutch size in arctic passerines. Ecol. Monogr., 42: 327-364.

Hákansson, E., O. Bennike, P. Mglgaard $P$. FrykMAN, 1981. Nordgrønlandske fugleobservationer, Somrene 1976 og 1978. Dansk orn. Foren. Tidsskr., 75: 51-67.

Johnsen, P., 1953. Birds and mammals of Peary Land in North Greenland. Meddr. Grønl., 128 (6): 64-65.

Just, J., 1967. Ornithologiske observationer på 4. Pearyland ekspedition sommeren 1966. Dansk orn. Foren. Tidsskr., 61: 133-137.

KampP, K., 1982. Notes on the Long-tailed Skua Stercorarius longicaudus in West Greenland. Dansk orn. Foren. Tidsskr., 76: 129-135.

Korte, J. DE, 1975. Golden Plover Pluvialis apricaria breeding in Jameson Land, East Greenland. Dansk orn. Foren. Tidsskr., 69: 129-134.

- , 1977. Ecology of the Long-tailed Skua Stercorarius longicaudus Vieillot, 1819 at Scoresby Sund, East Greenland. Part one: Distribution and density. Beaufortia, 25 (328): 201-219.

- , 1984. Ibid. Part two: Arrival, site tenacity and departure. Beaufortia, 34 (1): 1-14.

- , 1985. Ibid. Part three: Clutch size, laying date and incubation in relation to energy reserves. Beaufortia, 35 (6): 93-127.

Korte, J. DE, C. A. W. Bosman \& H. Meltofte, 1981. Observations on waders (Charadriidae) at Scoresby Sund, East Greenland. Meddr. Grønl., Bioscience, 7: 1-21.

Krechmar, A. V., 1966. The birds of the western parts of Taimyr Peninsula [in Russian]. Trans. zool. Inst. Moskou, Leningrad, 39: 266-268.

LACK, D., 1954. The natural regulation of animal numbers: 1-343 (Clarendon Press, Oxford).

LeCroy, M. \& C. T. Collins, 1972. Growth and survival of Roseate and Common tern chicks. Auk, 8: 595-611.

LeCroy, M. \&. LeCroy, 1974. Growth and fledging in the Common Tern (Sterna hirundo). Bird-Banding, 45: $326-340$.

Macpherson, A. H., 1969. The dynamics of Canadian Arctic Fox populations. Can. Wildlife Serv. Rep. Series, 8: 1-21.

Maher, W. J., 1970. Ecology of the Long-tailed Jaeger at Lake Hazen (Ellesmere Land). Arctic, 23 (2): 112-129.

- , 1974. Ecology of Pomarine, Parasitic and Longtailed Jaegers in Northern Alaska. Pacific Cst. Avifauna, 37: 1-148.

Manniche, A. L. V., 1910. The terrestrial mammals and birds of North-East Greenland. Biological observations. Meddr. Gronland, 45: 1-200.
Manning, T. H., E. O. Höhn \& A. H. Macpherson, 1956. The birds of Banks Island. Natn. Mus. Canada Bull., 143: 1-136.

Mayfield, H., 1961. Nesting success calculated from exposure. Wilson Bull., 73: 255-261.

-, 1975 . Suggestions for calculating nest success. Wilson Bull., 87: 456-466.

Meltofte, H., 1975. Ornithological observations in northeast Greenland between $76^{\circ} 00^{\prime}$ and $78^{\circ} 00^{\prime} \mathrm{N}$. lat. 1969-'71. Meddr. Grønl., 191 (9): 1-72.

- 1976 . Ornithological observations in Southern Peary Land, North Greenland, 1973. Meddr. Grønl., 205 (1): 1-57.

- , 1977. Ornithologiske observationer i Germanis Land, Nordøst Grønland, 1975. Dansk orn. Foren. Tidsskr., 71: 81-94.

-, 1985. Populations and breeding schedules of waders Charadriidae in high arctic Greenland. Meddr. Gronl., Bioscience, 16: 1-43.

Meltofte, H., M. Elander \& C. HJort, 1981. Ornithological observations in Northeast Greenland between $74^{\circ} 30^{\prime}$ and $76^{\circ} 00^{\prime} \mathrm{N}$. lat. 1976. Meddr. Gronl., Bioscience, 3: 1-53.

Nice, M. M., 1957. Nesting success in altricial birds. Auk, 74: 305-321.

Noordwijk, A. J. van, J. H. van Balen W. Scharloo, 1980. Heritability of ecologically important traits in the Great Tit. Ardea, 68: 193-203.

O'Connor, R. J., 1977. Differential growth and body composition in altricial passerines. Ibis, 119: 147-166.

O'Donald, P., 1983. The Arctic Skua, a study of the ecology and evolution of a seabird: 1-324 (Cambridge University Press, Cambridge).

Ojanen, M., M. Orell \& R. A. Väisänen, 1979. Role of heredity in egg-size variations in the Great Tit Parus major and Pied Flycatcher Ficedula hypoleuca. Ornis Scand., 10: 22-28.

Osborne, B. C., 1985. Aspects of the breeding biology and feeding behaviour of the Brown Skua Catharacta lönnbergi on Bird Island, South Georgia. Br. antarct. Surv. Bull., 66: 57-71.

Parmelee, D. F. S. D. MacDonald, 1960. The birds of west-central Ellesmere Island and adjacent areas. Natn. Mus. Canada Bull., 169: 1-103.

Parmelee, D. F., H. A. Stephens \& R. H. Schmidt, 1967. The birds of southeastern Victoria Island and adjacent small islands. Natn. Mus. Can. Bull., 222: 1-229.

Pedersen, A., 1926. Beiträge zur Kenntnis der Säugetierund Vogelfauna der Ostküste Grönlands. Meddr. Grønl., 68 (3): 208-249.

- , 1930. Fortgesetzte Beiträge zur Kenntnis der Säugetier- und Vogelfauna der Ostküste Grönlands. Meddr. Grønl., 77 (5): 426-501.

ostküste Grönlands. Meddr. Grønl., 100 (11): 1-35.

Portenko, L. A., 1973. The birds of the Chukotsk Penin- 
sula and Wrangel Island [in Russian], 2: 1-323 (Izdatel'stvo Nauka, Leningrad).

REID, B. E., 1966. The growth and development of the South Polar Skua. Notornis, 13: 71-89.

Ricklefs, R. E., 1967. A graphical method of fitting equations to growth curves. Ecology, 48: 978-983.

- , 1968. Patterns of growth in birds. Ibis, 110 (4): 419-451.

- , 1973. Patterns of growth in birds 2. Growth rate and mode of development. Ibis, 115 (2): 177-201.

- 1983. Avian postnatal development. In: D. S. Farner, J. R. King \& K. C. Parkes, eds., Avian biology, 7: 1-83 (Academic Press, New York, London).

Rosenberg, N. Th., N. Hesselbjerg Christensen \& B. GensBøL, 1970. Bird observations in Northeast Greenland. Meddr. Grønl., 191 (1): 1-87.

RøEN, U., 1965. Ornithologiske observationer på 3. Pearyland expedition sommeren 1964. Dansk. orn. Foren. Tidsskr., 59: 85-91.

Salomonsen, F., 1950. Gronlands Fugle (The birds of Greenland): 1-609 (E. Munksgaard, København).

- , 1972. Zoogeographical and ecological problems in arctic birds. Proc. 15th int. orn. Congr., The Hague, 1970: 25-77.

Sandell, H. B. Sandell, 1984. Kap Hope - en fangerbygd. Grønland, 8-9: 269-280.
Savile, D. B. O. \& D. R. Oliver, 1964. Bird and mammal observations at Hazen Camp, northern Ellesmere Island, in 1962. Can. Field Natural., 78: 1-7.

Schaanning, H. T. L., 1916. Bidrag til Novaja Semljas fauna. Dansk orn. Foren. Tidsskr., 10: 145-190.

SpellerberG, I. F., 1971. Breeding behaviour of the MacCormick Skua Catharacta maccormicki in Antarctica. Ardea, 59: 189-230.

TAYLOR, P. S., 1974. Summer populations and food ecology of Jaegers and Snowy Owls on Bathurst Island N.W.T. Unpublished thesis Univ. Alberta, Edmonton: 1-168.

Thing, H., P. Henrichsen \& P. Lassen, 1984. Status of the Muskox in Greenland. Biol. Pap. Univ. Alaska, spec. Rep., 4: 1-6.

Väisänen, R. A., O. Hilden, M. Solkkeli \& S. Vuolanto, 1972. Egg dimension variation in five wader species: the role of heredity. Ornis fenn., 49: 25-44.

Venables, L. S. V. \& U. M. Venables, 1955. Birds and mammals of Shetland: 1-391 (Oliver Boyd, Edinburgh).

Vibe, C., 1967. Arctic animals in relation to climatic fluctuations. Meddr. Grønl., 170 (5): 1-227.

Wijnandrs, H., 1984. Ecological energetics of the Longeared Owl (Asio otus). Ardea, 72: 1-92. 